\title{
Jaguar Panthera onca population decline in the Upper Paraná Atlantic Forest of Argentina and Brazil
}

\author{
Agustín Paviolo, Carlos Daniel De Angelo, Yamil Edgardo Di Blanco and
}

Mario Santiago Di BitetTi

\begin{abstract}
The Green Corridor of Argentina and Brazil is the largest forest remnant of the Upper Paraná Atlantic Forest. The jaguar population of this region is highly fragmented and reduced. To assess the status of the subpopulation of jaguars of the Green Corridor we conducted four camera-trap surveys in three sites with different levels of protection. At Urugua-í (34 stations, 1,495 trap-days) we recorded one individual (minimum density $=0.12-0.33$ per $100 \mathrm{~km}^{2}$ ). At Yabotí Biosphere Reserve (42 stations, 1,871 trap-days) we recorded two individuals (minimum density $=0.11-0.25$ per $100 \mathrm{~km}^{2}$ ). At Iguazú National Park we conducted two surveys. In 2004 (39 stations, 1,839 trap-days) we recorded four adult individuals, estimating a density of between $0.49 \pm 0.16$ and $1.07 \pm 0.33$ per $100 \mathrm{~km}^{2}$. In 2006, we increased the area sampled (47 stations, 2,059 trap-days) and recorded 11 adult individuals, estimating a density of $0.93 \pm 0.2$ to $1.74 \pm$ 0.34 per $100 \mathrm{~km}^{2}$. These density estimates are the lowest recorded for the species. Estimates for Iguazú are between 2-7.5 times lower than those reported in the early 1990s. This population decline probably results from the interaction of several factors, including lack of prey as a result of poaching and persecution. We estimate that there is currently a population of 25-53 adult jaguars in the Green Corridor. In spite of having sufficient potential habitat available this population is threatened and urgent conservation action is required.
\end{abstract}

Keywords Argentina, Atlantic Forest, camera trap, density estimate, Green Corridor, jaguar, Panthera onca, poaching.

\section{Introduction}

7 he jaguar Panthera onca is the largest felid of the 1 Americas. During the 2oth century its distribution was reduced to almost half of its original range (Sanderson et al., 2002). This reduction was particularly severe in Argentina (Perovic, 2002) and the species now occurs in only three

\footnotetext{
Agustín Paviolo (Corresponding author), Carlos Daniel De Angelo and Mario Santiago Di Bitetti National Research Council of ArgentinaLaboratorio de Investigaciones Ecológicas de las Yungas, Universidad Nacional de Tucumán and Centro de Investigaciones del Bosque Atlántico, Yapeyú, 23, CP 3370 Puerto Iguazú, Misiones, Argentina. E-mail paviolo4@arnet.com.ar

YAMIL EdGARdo Di Blanco Centro de Investigaciones del Bosque Atlántico, Yapeyú, 23, CP 3370 Puerto Iguazú, Misiones, Argentina.

Received 4 April 2007. Revision requested 20 August 2007. Accepted 3 December 2007.
}

isolated areas in the north (Altrichter et al., 2006; Di Bitetti et al., 2006a). The jaguar is considered a threatened species in Argentina (Díaz \& Ojeda, 2000), and is categorized as a National Natural Monument (Ley No. 25463, 2001). In Brazil it is considered threatened (Reis et al., 2006) and it has disappeared from most of the Atlantic Forest, where only a few small and isolated populations remain (Leite et al., 2002; Cullen et al., 2005).

Globally the Atlantic Forest of South America is one of the most threatened rainforests. Distributed across northeast Argentina, south-west Brazil and eastern Paraguay, the Upper Parana Atlantic Forest is the innermost region of the Atlantic Forest complex (Di Bitetti et al., 2003) but is being reduced and fragmented as a result of its conversion to other land uses (Holz \& Placci, 2003).

The largest remnant of the Upper Paraná Atlantic Forest, known as the Green Corridor (c. 10,00o km², Fig. 1a) lies in the Misiones Province of Argentina and neighbouring areas of Brazil. The Corridor holds the southernmost population of jaguars and has been identified as a high priority area for the conservation of the species because of its long-term conservation potential and its ecological uniqueness (Sanderson et al., 2002; Marieb, 2006). This jaguar population is the only one that has received that category in Argentina and in the Atlantic Forests (Eizirik et al., 2002; Sanderson et al., 2002).

Crawshaw (1995) provided relevant ecological information for this jaguar population, including home range size, population density and diet, and identified important threats. However, the decline in the rate of observed jaguar signs and in the number of reported attacks on domestic animals suggest that its population could have declined since the 1990s (Crawshaw, 2002).

The goal of this study was to estimate jaguar population densities widely across the Green Corridor and thus make a robust estimate of population size, assess the species' conservation status, and compare the population estimate with earlier values from the region (Crawshaw, 1995; Cullen et al., 2005) to assess population trends.

\section{Study area}

The Green Corridor is dominated by semi-deciduous forest and has a humid subtropical climate with hot summers (December-March) and winters with frosts (June-August). Mean total annual precipitation is $1,700-2,200 \mathrm{~mm}$, with no marked dry season (Crespo, 1982). 

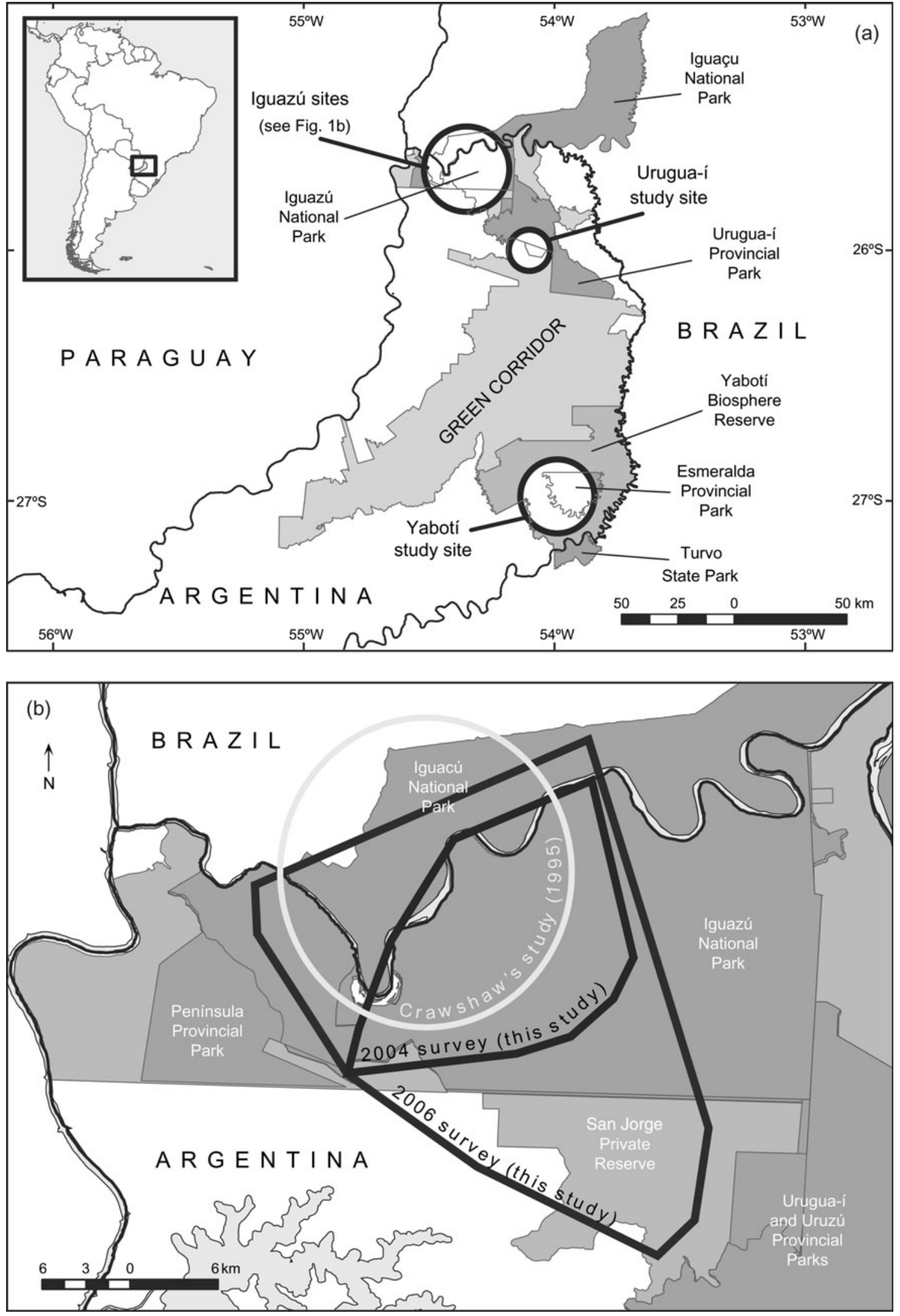

FIG. 1 (a) The Green Corridor of Argentina and Brazil and its main protected areas; the circles indicate the three study sites. The rectangle on the inset illustrates the location of the main map at the border between Argentina and Brazil. (b) The Iguazú study site, showing the minimum convex polygons that include all the camera-trap stations during the surveys of 2004 and 2006, and Crawshaw's (1995) study area. 
We conducted the first camera-trap survey at Urugua-i in 2003 in an area that comprises the Urugua-í Private Wildlife Reserve $\left(32 \mathrm{~km}^{2}\right)$, a portion of the Urugua-í Provincial Park $\left(840 \mathrm{~km}^{2}\right)$ and a portion of Campo Los Palmitos (300 $\left.\mathrm{km}^{2}\right)$, which belongs to a timber company and contains old pine (Pinus taeda and Pinus ellioti) plantations in a matrix of native forest (Fig. 1a). This forest was selectively logged until the beginning of the 1990 s but is in a relatively good condition (Di Bitetti et al., 2006b). Lack of resources precludes effective control of poaching, and the area suffers a moderate to high hunting pressure (Table 1).

The second study site is Iguazú, which we surveyed twice, in 2004 and in 2006-2007. The first survey comprised the central area of the Iguazú National Park of Argentina $\left(670 \mathrm{~km}^{2}\right.$, Fig. 1). This is the best-protected area of the region (Giraudo et al., 2003) and suffers a relatively low

TABLE 1 Area, law enforcement capacity and evidence of poaching in the three surveyed areas (Iguazú was surveyed in both 2004 and 2006; Fig. 1).

\begin{tabular}{|c|c|c|c|c|}
\hline \multirow[b]{2}{*}{ Measure of hunting pressure } & \multicolumn{4}{|c|}{ Iguazú, Iguazú, } \\
\hline & Urugua-í & 2004 & 2006 & Yabotí \\
\hline \multicolumn{5}{|l|}{ Law enforcement capacity } \\
\hline Area $\left(\mathrm{km}^{2}\right)$ & 1,132 & 670 & 2,694 & 3,160 \\
\hline Number of rangers & 9 & 25 & 70 & 7 \\
\hline Number of vehicles & 3 & 4 & 9 & 3 \\
\hline Rangers $\mathrm{km}^{-2}$ & 0.8 & 3.73 & 2.6 & 0.22 \\
\hline Vehicles $\mathrm{km}^{-2}$ & 0.27 & 0.6 & 0.33 & 0.1 \\
\hline $\begin{array}{l}\text { Use of fire arms by } \\
\text { rangers }\end{array}$ & No & Yes & Yes & No \\
\hline \multicolumn{5}{|l|}{ Evidence of hunting } \\
\hline Encounters with hunters & 4 & 0 & 1 & 2 \\
\hline Encounters with dogs & 4 & 0 & 0 & 0 \\
\hline $\begin{array}{l}\text { Photographic records of } \\
\text { dogs or people }\end{array}$ & 4 & 2 & 6 & 8 \\
\hline Hunting camp sites & 6 & 0 & 0 & $>3^{1}$ \\
\hline $\begin{array}{l}\text { Artificial salt licks or } \\
\text { poaching platforms }\end{array}$ & 3 & 0 & 0 & 4 \\
\hline Gunshots heard $^{2}$ & 5 & 1 & 0 & 0 \\
\hline Hunting trails & 7 & 0 & 0 & $0^{3}$ \\
\hline Spent shotgun cartridges & 1 & 0 & 0 & 2 \\
\hline $\begin{array}{l}\text { Human tracks not } \\
\text { associated with logging } \\
\text { activities or patrols } \\
\text { by rangers }\end{array}$ & 2 & 0 & 0 & $0^{4}$ \\
\hline $\begin{array}{l}\text { Camera trap stations } \\
\text { robbed or destroyed }\end{array}$ & 0 & 0 & 3 & 1 \\
\hline
\end{tabular}

${ }^{1}$ This is an underestimate. We found three hunters' camp sites but there were many logging camps, employees of which usually hunt at the weekends. On the two occasions we found spent shotgun cartridges it was at logging camps.

${ }^{2}$ Number of independent events, at each of which we may have heard $>1$ shot.

${ }^{3}$ At Yabotí we opened few trails and this reduced the likelihood of crossing or detecting hunting trails.

${ }^{4}$ Most private properties were under logging operations and we were not able to distinguish tracks of workers from those of poachers. hunting frequency, restricted mainly to the park edges (Table 1). In the second survey we expanded the sampled area to cover most of Iguazú National Park, the whole San Jorge Forest Reserve and the western area of the Brazilian Iguaçu National Park of 1,850 $\mathrm{km}^{2}$ (Fig 1 b). The surveyed area overlaps extensively with Crawshaw's (1995) study area (Fig. 1b). The absence of a buffer zone and the extensive edge of the western portion of the Brazilian Park makes this area accessible to poachers (Crawshaw, 2002). The San Jorge Forest Reserve $\left(174 \mathrm{~km}^{2}\right)$ is owned by a timber company and is covered by native forest that was selectively logged until 20 years ago (O. Lescano, pers. comm.).

The third study site is in the Yabotí Biosphere Reserve $\left(2,600 \mathrm{~km}^{2}\right)$, which we surveyed in 2005 , and comprises private properties with forest that are being currently logged $\left(2,200 \mathrm{~km}^{2}\right)$. It also comprises Esmeralda Provincial Park (300 km², logged until 1990). Poachers frequently arrive from villages located outside the reserve and from the Brazilian border. Anti-poaching control is insufficient and the area suffers moderate to high hunting pressure (Table 1).

\section{Methods}

To estimate jaguar densities we used a standard cameratrapping protocol (Karanth, 1995; Karanth \& Nichols, 1998) that has been used to estimate jaguar densities (Wallace et al., 2003; Maffei et al., 2004; Silver et al., 2004; Cullen et al., 2005; Soisalo \& Cavalcanti, 2006; Salom-Pérez et al., 2007). The method makes use of capture-mark-recapture closed population models to estimate animal densities (Otis et al., 1978). Individuals are identified in photographs by their distinctive spotted coat. From the capture-recapture history of individuals we estimated population size (Karanth, 1995).

At each study site we set $34-47$ sampling stations (Table 2), each of which consisted of a pair of camera traps operating independently and facing each other. The stations were located at regular intervals on trails and rarely-used dirt roads. Prior to the full survey period we conducted preliminary surveys of $4-7$ months to identify promising sites for placing the stations. Each full survey lasted 96 days. During this period we set up camera traps in half of the sampling stations for the first half of the survey period (day 1-(45-50)), after which we moved the stations to the remaining sampling stations for the rest of the study period (day (45-50)-96).

In Urugua-í and Yabotí we could not estimate the abundance of jaguars by means of capture-recapture population models because of the small number of individuals recorded. In these sites we provide an estimate of a minimum number of individuals present in the area from the photographs obtained by camera traps and the observation of jaguar tracks. To estimate jaguar abundance at Iguazú we used the software CAPTURE (Rexstad \& 
TABLE 2 Number of camera-trap stations, mean distance between stations, date of the full survey, and survey effort for full and for both surveys combined, in the three surveyed areas (Iguazú was surveyed in both 2004 and 2006; Fig. 1).

\begin{tabular}{|c|c|c|c|c|c|}
\hline Site & $\begin{array}{l}\text { No. of } \\
\text { stations }\end{array}$ & $\begin{array}{l}\text { Mean }( \pm S E) \\
\text { distance } \\
\text { between stations } \\
(\mathrm{km})\end{array}$ & $\begin{array}{l}\text { Date of full } \\
\text { survey }\end{array}$ & $\begin{array}{l}\text { Full survey } \\
\text { effort (trap } \\
\text { days) }\end{array}$ & $\begin{array}{l}\text { Total survey } \\
\text { effort }^{*} \text { (trap } \\
\text { days) }\end{array}$ \\
\hline$\overline{\text { Urugua-í }}$ & 34 & $1.25 \pm 0.46$ & Dec. 2003-Feb. 2004 & 1,495 & 2,611 \\
\hline Iguazú, 2004 & 39 & $2.08 \pm 0.41$ & Aug.-Nov. 2004 & 1,839 & 2,942 \\
\hline Iguazú, 2006 & 47 & $2.58 \pm 0.60$ & Oct. 2006-Jan. 2007 & 2,059 & 2,287 \\
\hline Yabotí & 42 & $2.43 \pm 0.81$ & Sep.-Dec. 2005 & 1,871 & 2,676 \\
\hline
\end{tabular}

${ }^{\star}$ Includes effort of the preliminary and full surveys

Burnham, 1991), which provides population estimates using various models (Otis et al., 1978; White et al., 1982). We report the results of model $\mathrm{M}_{\mathrm{h}}$ using a Jackknife estimator. $\mathrm{M}_{\mathrm{h}}$ assumes heterogeneity among individuals in their capture probabilities and is the most appropriate model because of the unequal access to sampling stations by different individuals (Karanth \& Nichols, 2002). We divided the survey period into 16 trapping occasions of 6 consecutive days each with the aim of having a capture probability higher than 0.1 , as recommended by Otis et al. (1978) and White et al. (1982). Finally, we performed the closure test provided by CAPTURE to test the closed population assumption.

To estimate density it is necessary to calculate the area effectively sampled. This is usually accomplished by applying to each sampling station a buffer equivalent to $1 / 2$ of the mean maximum distance of recaptures (MMDM) for the individuals recorded at more than one station (Silver et al., 2004). However, in some situations using $1 / 2 \mathrm{MMDM}$ as the buffer could inflate density estimates (Trolle \& Kéry, 2003; Soisalo \& Cavalcanti, 2006; Maffei \& Noss, 2007) and, if radiotelemetry data exist, the best buffer should be the radius of the estimate of mean home range (Soisalo \& Cavalcanti, 2006). We provide three density estimates using different buffers to estimate the effectively sampled areas: (1) the radius of the mean adult home range ( $\mathrm{n}=3$ individuals) from Crawshaw (1995); (2) 11/2 MMDM; (3) MMDM. Because of the small number of jaguars photographed we calculated MMDM as the mean maximum distance moved by all the individuals with recaptures at more than one station, pooling the data from the four surveys $(n=8)$. For individuals that were captured (and recaptured at $>_{1}$ station) in the two surveys at Iguazú $(\mathrm{n}=2)$, we averaged their maximum distance moved (MDM) for both surveys, thus contributing only one value each to the estimate of MMDM. After applying the buffer to the sampling stations we subtracted, from the total area thus obtained, the portions of unsuitable jaguar habitat (e.g. cities, annual crops, airports) to estimate the effectively surveyed area. We used the geographical information system ArcView v. 3.2 (ESRI, Redlands, USA) to estimate MMDM values and surveyed areas.
We used an ANOVA, and post hoc comparisons among samples using the Tukey-Kramer test, to compare our estimates of jaguar density with others for the same region (Iguazú: Crawshaw, 1995; Morro do Diabo State Park: Cullen et al., 2005) and with other published estimates from across the jaguar's range (Ceballos et al., 2002; Nuñez et al., 2002; Maffei et al., 2004; Silver et al., 2004; Soisalo \& Cavalcanti, 2006; Salom-Pérez et al., 2007). For these comparisons we used our estimates obtained using $1 / 2 \mathrm{MMDM}$ as the buffer. For Iguazú we used only one density value (the mean of the two surveys). After checking for deviations from normality we performed the ANOVA with $\ln$ (density).

To estimate the population of adult jaguars in the Green Corridor we first appraised the area of potential jaguar habitat by using detailed jaguar presence information obtained in 4 years of intensive large-scale census of jaguar presence (C.D. De Angelo, unpubl. data), and then digitized forest and plantation cover that surrounded jaguar presence points from 2004 Landsat satellite images using ArcView. We categorized this potential area into three habitat categories: (1) not suitable (jaguars absent), (2) well protected, and (3) poorly protected. Finally, we extrapolated our maximum and minimum density estimates for areas with low protection (mean of Yabotí and Urugua-í) and high protection (mean of the Iguazú surveys) to the available area in categories 2 and 3 of habitat quality to estimate the number of jaguars.

\section{Results}

We photographed 13 different adult jaguars during the four surveys, eight at more than one station. The maximum (25.08 $\mathrm{km})$ and minimum $(2.35 \mathrm{~km})$ distances of recapture were for an adult male and female, respectively, at Iguazú. The MMDM was $11.33 \pm \mathrm{SE} 2.7 \mathrm{~km}(\mathrm{n}=8)$, which is not statistically different from the mean diameter of the home ranges of the adult jaguars estimated by Crawshaw (1995; $8.55 \pm$ SE $1.45 \mathrm{~km}$, $\mathrm{n}=3$; ANOVA $F=0.36, \mathrm{P}=0.563)$.

Urugua-í We recorded only one individual, an adult male, captured twice (at two sampling stations; $\mathrm{MDM}=9.44 \mathrm{~km}$ ) 
during the full survey and once during the preliminary survey. Jaguar tracks were found only three times and probably belonged to the photographed jaguar, because they were similar in size. Considering the low occurrence of tracks and the low number of photographic captures (Table 3), it is possible that the animal photographed could have been the only resident jaguar in the surveyed area. The effectively sampled area varied widely $\left(299.01-823.63 \mathrm{~km}^{2}\right)$ depending on the buffer used. We estimate a minimum density of 0.12-0.33 per $100 \mathrm{~km}^{2}$ at Urugua-í (Table 2).

Iguazú During the first full survey we obtained 10 photographs of four different adults (three females, one male). We also photographed two other jaguars that were not included in the analyses because they were captured outside the full survey period of 96 days. CAPTURE indicate that this population is not different from a closed one $(z=-0.942$, $\mathrm{P}=0.173)$ and estimated a population of $5 \pm$ SE 1.41 adults. The effectively sampled area was $467.65-1,023.78 \mathrm{~km}^{2}$, depending on the buffer used (Table 3 ). We estimated an adult jaguar density of between $0.49 \pm$ SE 0.16 and $1.07 \pm$ SE 0.33 per $100 \mathrm{~km}^{2}$ (Table 3). During the second survey we obtained 28 photographs of 11 different adult individuals (six females, four males, one unsexed individual), four of which were photographed during the 2004 survey. Two of the females were photographed with large cubs (c. 1 year old). CAPTURE indicated there was no violation of the closed population assumption $(z=-1.392, \mathrm{P}=$ 0.082 ) and estimated an adult population of $14 \pm$ SE 2.45 . The estimated sampled area was $804.88-1,499.52 \mathrm{~km}^{2}$, depending on the buffer. We estimated an adult jaguar density of between $0.93 \pm$ SE 0.2 and $1.74 \pm$ SE 0.34 per $100 \mathrm{~km}^{2}$ (Table 3).

Yabotí We photographed only one male, recorded once and three times during the preliminary and full surveys, respectively. We recorded large tracks (right front track 12.1 $\mathrm{cm}$ long $\times 13.1 \mathrm{~cm}$ wide), most probably belonging to the photographed male, and medium size tracks (right front track $9.1 \mathrm{~cm}$ long $\times 10.6 \mathrm{~cm}$ wide) probably from an adult female or a subadult male. Thus, the surveyed area was occupied by at least two jaguars, giving a minimum estimate of $0.11-0.25$ per $100 \mathrm{~km}^{2}$ (Table 2).

There are statistically significant differences between the estimated jaguar densities at the three study sites and those obtained in the same area $>10$ years before or in other portions of the same region $(n=2)$ and with other jaguar studies $\quad\left(\mathrm{n}=10 ; \quad\right.$ ANOVA $\quad F_{2,12}=17.49, \quad \mathrm{P}=0.0003$; Fig. 2). Tukey-Kramer comparisons among samples indicated that the jaguar densities of the Green Corridor $\left(\right.$ mean $=0.545 \pm$ SE 0.31 per $\left.100 \mathrm{~km}^{2}\right)$ are lower than those of other sites outside the Upper Paraná Atlantic Forest $\left(5.243 \pm\right.$ SE 0.77 per $\left.100 \mathrm{~km}^{2}\right)$ and those previously obtained in the Green Corridor or in other fragments of the Upper Paraná Atlantic Forest $\left(2.96 \pm\right.$ SE 0.74 per $\left.100 \mathrm{~km}^{2}\right)$. The latter two estimates are not statistically different.

We calculated an area of $9,234 \mathrm{~km}^{2}$ of habitat with potential jaguar presence in the Green Corridor. The extrapolation of the minimum and maximum jaguar density estimates to the available areas of high and low protection

TABLE 3 Number of jaguar photo-captures per 1,00o trap-days, number of adult jaguars recorded, population estimate, buffer applied for calculations (see text for further details), area surveyed, and density estimates for each of the four full camera-trap surveys.

\begin{tabular}{|c|c|c|c|c|c|c|}
\hline Site & $\begin{array}{l}\text { Jaguar } \\
\text { captures } \\
\text { per } 1,000 \\
\text { trap-days }\end{array}$ & $\begin{array}{l}\text { No. of } \\
\text { adult } \\
\text { jaguars } \\
\text { recorded }\end{array}$ & $\begin{array}{l}\text { Population } \\
\text { estimate } \\
\pm \mathrm{SE}\end{array}$ & $\begin{array}{l}\text { Buffer } \\
\text { applied } \\
(\mathrm{km})\end{array}$ & $\begin{array}{l}\text { Surveyed } \\
\text { area } \\
\left(\mathrm{km}^{2}\right)\end{array}$ & $\begin{array}{l}\text { Density } \\
\text { estimate } \\
\pm \mathrm{SE} \\
\left(100 \mathrm{~km}^{-2}\right)\end{array}$ \\
\hline \multirow[t]{3}{*}{ Urugua-í } & 1.34 & 1 & $1^{2}$ & $4.28^{3}$ & 299.01 & $0.33^{4}$ \\
\hline & & & & $5.67^{5}$ & 367.69 & $0.27^{4}$ \\
\hline & & & & $11.33^{6}$ & 823.63 & $0.12^{4}$ \\
\hline \multirow[t]{3}{*}{ Iguazú, 2004} & 5 & 4 & $5 \pm 1.41^{7}$ & $4.28^{3}$ & 467.65 & $1.07 \pm 0.33$ \\
\hline & & & & $5.67^{5}$ & 576.61 & $0.87 \pm 0.3$ \\
\hline & & & & $11.33^{6}$ & $1,023.78$ & $0.49 \pm 0.16$ \\
\hline \multirow[t]{3}{*}{ Iguazú, 2006} & 14 & 11 & $14 \pm 2.45^{7}$ & $4.28^{3}$ & 804.88 & $1.74 \pm 0.34$ \\
\hline & & & & $5.67^{5}$ & 958.16 & $1.46 \pm 0.34$ \\
\hline & & & & $11.33^{6}$ & $1,499.52$ & $0.93 \pm 0.2$ \\
\hline \multirow[t]{3}{*}{ Yabotí } & 1.63 & 2 & $2^{2}$ & $4.28^{3}$ & 807.94 & $0.25^{4}$ \\
\hline & & & & $5.67^{5}$ & $1,000.67$ & $0.2^{4}$ \\
\hline & & & & $11.33^{6}$ & $1,762.62$ & $0.11^{4}$ \\
\hline
\end{tabular}

\footnotetext{
${ }^{1}>1 \mathrm{~h}$ had to pass for consecutive photographs of a jaguar to be considered independent records

${ }^{2}$ Number of jaguars recorded in the study area during the survey

$3 \frac{1}{2}$ of the radius of the mean adult home range estimates $(n=3)$ from Crawshaw (1995)

${ }^{4}$ Minimum density estimate

$5 \frac{1}{2}$ of the mean maximum distance of recapture ( $1 / 2$ MMDM) for all the individuals recaptured at $>1$ sampling station during the four surveys

${ }^{6}$ Mean maximum distance of recapture (MMDM) for all individuals recaptured at $>1$ sampling station during the four surveys

${ }^{7}$ Abundance estimate obtained with CAPTURE (Rexstad \& Burnham, 1991) using model $\mathrm{M}_{\mathrm{h}}$
} 


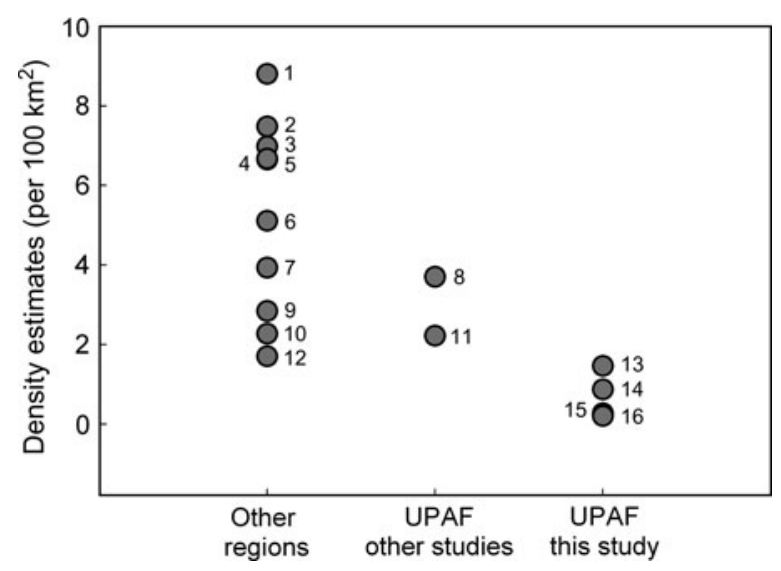

Fig. 2 Estimates of jaguar density in the Upper Paraná Atlantic Forest (UPAF) from this $(13,14,15,16)$ and other studies (8, Iguazú: Crawshaw, 1995; 11, Morro do Diabo State Park: Cullen et al., 2005), and from other regions (1, 2, 6, 7, 9, Silver et al., 2004; 3, Salom-Pérez et al., 2007; 4, Ceballos et al., 2002; 5, Soisalo \& Cavalcanti, 2006; 10, Maffei et al., 2004; 12, Nuñez et al., 2002).

results in an estimate of $25-53$ adult jaguars in the Green Corridor.

\section{Discussion}

Jaguars currently occur at low densities in the Green Corridor of Argentina and Brazil. Our estimates of density are the lowest obtained for the species across its range, and lower than those obtained by Crawshaw (1995) in the same area and by Cullen et al. (2005) in the northern part of the same region. We believe we have documented a decline that has taken place since the early 1990s. At Iguazú our estimates are 2-7.5 times lower than the 3.7 jaguars per $100 \mathrm{~km}^{2}$ calculated by Crawshaw in 1995 (Fig. 2). The diminution of jaguar signs (Crawshaw, 2002) and fewer recorded attacks by jaguar on domestic animals during the last few years (K. Schiaffino, pers. comm.) also suggest that jaguars are now less abundant.

Our low density estimates in comparison to other studies could have resulted from methodological differences or sampling artefacts but ancillary evidence suggests our estimates are reliable. Firstly, our sampling effort was similar or greater than that of other studies in terms of the number of stations and trap-days, and our camera-trap surveys at Yabotí and Iguazú are probably the largest ever conducted for jaguars in terms of the area sampled (A. Noss, pers. comm.). Secondly, although Crawshaw (1995) used radio-telemetry other studies estimated similar jaguar densities using both radio-telemetry and camera trapping in the same region (Cullen et al., 2005), and our ocelot density estimates for Iguazú using camera traps are not different from Crawshaw's (1995) estimate using radiotelemetry (Di Bitetti et al., 2006b, 2008a).

The slightly higher jaguar density recorded in the 2006 survey at Iguazú may be related to the inclusion of San Jorge Forest Reserve (c. $25 \%$ of the sampled area), where six of the eleven adults photographed were recorded. This, and the fact that San Jorge is located in a strategic area serving as a connection between Iguazú National Park and Urugua-í Provincial Park, (Fig. 1b) suggest that this is an important area for jaguar conservation.

It was previously assumed that Crawshaw's density estimates for Iguazú were representative of the whole Green Corridor (Eizirik et al., 2002). For Urugua-í and Yabotí we only have conservative density estimates and there is no previous information to ascertain whether there has been a population decline in these areas as well. However, the fact that we photographed only one jaguar at each site, despite the long duration of the surveys and the large areas studied, the difficulty of finding jaguar tracks, and the low jaguar recording rate compared to similar studies (Table 1; Maffei et al., 2004) indicate that jaguar densities are currently extremely low in these areas.

Low availability of prey could have affected this population. A good prey base is essential for the maintenance of healthy jaguar populations (Hoogesteijn \& Mondolfi, 1992; Crawshaw, 1995). In Misiones poaching is common and can reduce prey availability (Paviolo, 2002). Our camera trap records of collared peccaries Pecari tajacu, tapirs Tapirus terrestris and red brocket deers Mazama americana were also fewer in Urugua-í and Yabotí (with high hunting pressure) than in Iguazú (Di Bitetti et al. 2008b; A. Paviolo et al., unpubl. data). Densities of other large carnivores such as pumas and ocelots are also lower at Yabotí and Urugua-í (Di Bitetti et al., 2006b, 2008a; A. Paviolo et al., unpubl. data), suggesting they are probably affected by similar factors.

In the northern part of the Green Corridor (including Iguazú and Urugua-í), white-lipped peccaries Tayassu pecari have declined. In the early 1990 s they were abundant and comprised the most important prey item in the jaguar's diet (Crawshaw, 1995). This species has not been recorded since 2000 in the Iguaçú National Park of Brazil (A. Ricieri, pers. comm.). We did not record it in our survey at Uruguaí and it was rarely recorded during the two surveys at Iguazú National Park, and in unusually small herds (A. Paviolo et al., unpubl. data). The scarcity of this major prey species could have affected jaguars in this area but does not explain the low density of jaguars at Yabotí, where we observed and recorded white-lipped peccaries in large herds.

Even though jaguars are protected by law in Argentina and Brazil they are regularly killed. Jaguar poaching was an important source of mortality in the Iguaçu National Park (Crawshaw, 1995), and jaguars are also killed because they occasionally prey on domestic animals (Schiaffino et al., 2002) and because people consider them dangerous (Conforti \& Azevedo, 2003). Between 1995 and 2002 at least 70 jaguars were killed in areas neighbouring Iguaçú National Park (Crawshaw, 2002), and during the last 10 years at least 47 were killed in Northern Misiones (A. Paviolo, unpubl. data). 
The conversion of forests into other land uses is an ongoing process that reduces the availability of adequate habitat for jaguars, fragments forest and facilitates poaching in areas that were previously relatively inaccessible. The decline of the jaguar population of the Green Corridor, estimated to number several hundreds c. 15 years ago (Eizirik et al., 2002) but now comprising $<60$ adult animals, may have resulted from the interaction of these factors. Because this population is at the southernmost limit of the species' range its conservation has special relevance. Its disappearance would be one of the final steps towards the extinction of the species in Argentina, where other jaguar populations are also threatened (Altrichter et al., 2006; Di Bitetti et al., 2006a).

However, the population of jaguars in the Upper Paraná Atlantic Forest is still that with the greatest potential for long-term persistence in the Atlantic Forest, despite its relatively small size. To mitigate the impact of the main threats and allow the jaguar population to recover we recommend five actions: (1) Halt the killing of jaguars and their prey, by reinforcing anti-poaching measures both inside and outside protected areas. (2) Implement the existing protected areas and create new ones in strategic locations to improve connectivity between forest areas, thus conserving important habitat and limiting access for poachers. (3) Reduce conflict between cattle ranchers and jaguars by compensating ranchers for losses but also demanding better management practices and penalizing those who kill jaguar. (4) Change human perceptions of the danger from jaguars and inform the public about the species' conservation status using campaigns and environmental education programmes (an example of which is Campaña Yaguareté, 2007, an education campaign recently launched by local NGOs and governmental agencies). (5) Coordinate joint conservation efforts between government institutions in Argentina and Brazil and NGOs (Paviolo et al., 2006). We are now working in partnership with these institutions to develop a recovery plan for the jaguar population of the Green Corridor (Chalukian et al., 2006).

\section{Acknowledgements}

We are grateful to all the volunteers and park rangers who helped us with field work. We acknowledge the support and permits provided by the Ministry of Ecology, Natural Resources and Tourism of Misiones province (MERNRT) and the National Parks Administration of Argentina. We are grateful to Fundación Vida Silvestre Argentina and the property owners for their support and permission to conduct this work. Financial support was provided by CONICET, Fundación Vida Silvestre Argentina, WWFUSA, WWF-International, WWF-Switzerland, Lincoln Park Zoo, Fundación Antorchas, the Wildlife Conservation Society, Idea Wild, the Rufford Foundation, MERNRT, and the Eden Project through a grant from the Darwin Initiative. We also thank Lía Montti, Andy Noss, Cristina de De Angelo, Peter Crawshaw and an anonymous reviewer for help and comments on the manuscript.

\section{References}

Altrichter, M., Boaglio, G. \& Perovic, P. (2006) The decline of jaguars Panthera onca in the Argentine Chaco. Oryx, 40, 302-309.

Campaña Yaguareté (2007) Gobierno de Misiones, Administración de Parques Nacionales y Fundación Vida Silvestre Argentina [http://www.yaguarete.net, accessed 20 June 2008].

Ceballos, G., Chávez, C., Rivera, A., Manterota, C. \& Wall, B. (2002) Tamaño poblacional y conservación del jaguar en la Reserva de Biósfera Calakmul, Campeche, Mexico. In El jaguar en el nuevo milenio (eds R.A. Medellín, C. Equihua, Ch.L. Chetkiewicz, P.G. Crawshaw, A. Rabinowitz, K.H. Redford et al.), pp. 403-417. Editorial Ediciones Científicas Universitarias, México DF, México.

Chalukian, S., Schiaffino, K., Sestello, A., Guerra, I., Moschione, F., Paviolo, A. et al. (2006) Informe del 2 do Taller Monumento Natural Nacional Yaguareté y 6to. Taller Monumento Natural Provincial Yaguareté, Posadas, Argentina [http://www.ambiente.gov.ar/archivos/web/DFS/File/Taller\%20 Yaguarete/Informe_final_taller_Yaguaret\%20_Posadas.pdf, accessed 4 July 2008].

Conforti, V.A. \& Azevedo, F.C.C. (2003) Local perceptions of jaguars Panthera onca and pumas Puma concolor in the Iguaçu National Park area, south Brazil. Biological Conservation, 111, 215-221.

Crawshaw, Jr, P.G. (1995) Comparative ecology of ocelot Felis pardalis and jaguar Panthera onca in a protected subtropical forest in Brazil and Argentina. DPhil thesis, University of Florida, Gainesville, USA.

Crawshaw, Jr, P.G. (2002) Mortalidad inducida por humanos y conservación de jaguares: el Pantanal y el Parque Nacional Iguaçu en Brasil. In El jaguar en el nuevo milenio (eds R.A. Medellín, C. Equihua, Ch.L. Chetkiewicz, P.G. Crawshaw, A. Rabinowitz, K.H. Redford et al.), pp. 451-464. Editorial Ediciones Científicas Universitarias, México DF, México.

Crespo, J.A. (1982) Ecología de la comunidad de mamíferos del Parque Nacional Iguazú, Misiones. Revista MACN, Ecología 3 , 45-162.

Cullen, Jr, L., Abreu, K.C., Sana, D. \& Ferreira Dales Nava, A. (2005) Jaguars as landscape detectives for the upper Paraná River corridor, Brazil. Natureza \& Conservação, 3, 43-58.

Di Bitetti, M.S., De Angelo, C., Paviolo, A. \& Di Blanco, Y. (2008a) Local and continental determinants of the abundance of a Neotropical cat, the ocelot (Leopardus pardalis). Journal of Tropical Ecology, 24, 189-200.

Di Bitetti, M.S., De Angelo, C., Paviolo, A., Schiafino, K. \& Perovic, P.G. (2006a) Monumento Natural Nacional en peligro: el desafío de conservar el yaguareté en la Argentina. In $\mathrm{La}$ Situación Ambiental Argentina 2005 (eds J. Corchera \& A. Brown), pp. 22-34. Fundación Vida Silvestre Argentina, Buenos Aires, Argentina.

Di Bitetti, M.S., Paviolo, A. \& De Angelo, C. (2006b) Density, habitat use, and activity patterns of ocelots Leopardus pardalis in the Atlantic Forest of Misiones, Argentina. Journal of Zoology, London, 270, 153-163.

Di Bitetti, M.S., Paviolo, A., Ferrari, C., De Angelo, C. \& Di Blanco, Y. (2008b) Differential responses to hunting in two 
sympatric species of brocket deer (Mazama americana and M. nana). Biotropica, doi:10.1111/j.1744-7429.2008.00413.x

Di Bitetti, M.S., Placci, G. \& Dietz, L.A. (2003) A Biodiversity Vision for the Upper Paraná Atlantic Forest Eco-region: Designing a Biodiversity Conservation Landscape and Setting Priorities for Conservation Action. WWF, Washington, DC, USA.

DíAz, G.B. \& OJEDA, R.A. (eds) (2000) Libro rojo de mamíferos amenazados de la Argentina. Sociedad Argentina para el Estudio de los Mamíferos, Buenos Aires, Argentina.

Eizirik, E., Indrusiak, C.B. \& Johnson, W.E. (2002) Análisis de la viabilidad de las poblaciones de Jaguar: evaluación de parámetros y estudios de caso en tres poblaciones remanentes del sur de Sudamérica. In El jaguar en el nuevo milenio (eds R.A. Medellín, C. Equihua, Ch.L. Chetkiewicz, P.G. Crawshaw, A. Rabinowitz, K.H. Redford et al.), pp. 501-518. Editorial Ediciones Científicas Universitarias, México DF, México.

Giraudo, A.R., Krauczuk, E., Arzamendia, V. \& Povedano, H. (2003) Critical analysis of protected areas in the Atlantic forest of Argentina. In State of the Hotspots: Atlantic Forest (eds C. Galindo-Leal \& I.G. Câmara), pp. 245-261. Center for Applied Biodiversity Science \& Island Press, Washington DC, USA.

Holz, S. \& PlACCI, G. (2003) Socioeconomic roots of biodiversity loss in Misiones. In State of the Hotspots: Atlantic Forest (eds C. Galindo-Leal \& I.G. Câmara), pp. 207-226. Center for Applied Biodiversity Science \& Island Press, Washington, DC, USA.

Hoogesteijn, R. \& Mondolfi, E. (1992) El jaguar o Tigre americano. Armitano, Caracas, Venezuela.

Karanth, K.U. (1995) Estimating tiger Panthera tigris populations from camera trap data using capture-recapture models. Biological Conservation, 71, 333-338.

KaRANTH, K.U. \& Nichols, J.D. (1998) Estimation of tiger densities in India using photographic captures and recaptures. Ecology, 79, 2852-2862.

Karanth, K.U. \& Nichols, J.D. (2002) Monitoring Tigers and Their Prey: A Manual for Researchers, Managers and Conservationists in Tropical Asia. Centre for Wildlife Studies, Bangalore, India.

Leite, M.R., Boulhosa, R.L.P., Galvao, F. \& Cullen, Jr, L. (2002) Conservación del jaguar en las áreas protegidas del Bosque Atlántico de Brasil. In El jaguar en el nuevo milenio (eds R.A. Medellín, C. Equihua, Ch.L. Chetkiewicz, P.G. Crawshaw, A. Rabinowitz, K.H. Redford et al.), pp. 25-42. Editorial Ediciones Científicas Universitarias, México DF, México.

Ley N ${ }^{\circ} 25463$ (2001) Boletín Oficial. 13 de Septiembre de 2001. Gobierno de la Nación Argentina, Buenos Aires, Argentina.

Maffei, L., Cuéllar, E. \& Noss, A. (2004) One thousand jaguars Panthera onca in Bolivia's Chaco? Camera trapping in the Kaa-Iya National Park. Journal of Zoology, 262, 295-304.

Maffei, L. \& Noss, A.J. (2007) How small is too small? Camera trap survey areas and density estimates for ocelots in the Bolivian Chaco. Biotropica, 40, 71-75.

Marieb, K. (2006) Jaguars in the New Millennium Dataset Update: The State of the Jaguar in 2005. Wildlife Conservation Society, New York, USA.

Nuñez, R., Miller, B. \& Lindzey, F. (2002) Ecología del jaguar en la Reserva de la biosfera Chamela-Cuixmala, Jalisco, México. In El jaguar en el nuevo milenio (eds R.A. Medellín, C. Equihua, Ch.L. Chetkiewicz, P.G. Crawshaw, A. Rabinowitz, K.H. Redford et al.), pp. 107-126. Editorial Ediciones Científicas Universitarias, México DF, México.

Otis, D.L., Burnham, K.P., White, G.C. \& Anderson, D.R. (1978) Statistical inference from capture data on closed animal populations. Wildife Monograph, 62, 1-135.
Paviolo, A. (2002) Abundancia de presas potenciales de yaguareté (Panthera onca) en áreas protegidas y no protegidas de la Selva Paranaense, Argentina. BSc thesis, Universidad Nacional de Córdoba, Córdoba, Argentina.

Paviolo, A., De Angelo, C., Di Blanco, Y., Ferrari, C., Di Bitetti, M.S., Kasper, C.B. et al. (2006) The need for transboundary efforts to preserve the southernmost jaguar population in the world. Cat News, 45, 12-14.

Perovic, P.G. (2002) Ecología de la comunidad de félidos en las selvas nubladas del noroeste argentino. $\mathrm{PhD}$ thesis, Universidad Nacional de Córdoba, Córdoba, Argentina.

Reis, N.R., Peracchi, A.L., Pedro, W.A. \& Lima, I.P. (eds) (2006) Mamíferos do Brasil. Londrina, Paraná, Brazil.

Rexstad, E. \& Burnham, K.P. (1991) User's Guide for Interactive Program CAPTURE. Abundance Estimation of Closed Populations. Colorado State University, Fort Collins, USA.

Salom-Pérez, R., Carrillo, E., Sáenz, J.C. \& Mora, J.M. (2007) Critical condition of the jaguar Panthera onca population in Corcovado National Park, Costa Rica. Oryx, 41, 51-56.

Sanderson, E.W., Redford, K.H., Chetriewicz, C.B., Medellin, R.A., Rabinowitz, A.R., Robinson, J.G. \& Taber, A.B. (2002) Planning to save a species: the jaguar as a model. Conservation Biology, 16, 58-71.

Schiafino, K., Malmierca, L. \& Perovic, P.G. (2002) Depredación de cerdos domésticos por jaguar en un área rural vecina a un Parque Nacional en el noreste de Argentina. In El jaguar en el nuevo milenio (eds R.A. Medellín, C. Equihua, Ch.L. Chetkiewicz, P.G. Crawshaw, A. Rabinowitz, K.H. Redford et al.), pp. 251-264. Editorial Ediciones Científicas Universitarias, México DF, México.

Silver, S.C., Ostro, L.E.T., Marsh, L.K., Maffei, L., Noss, A.J., Kelly, M.J. et al. (2004) The use of camera traps for estimating jaguar Panthera onca abundance and density using capture/ recapture analysis. Oryx, 38, 148-154.

Soisalo, M.K. \& Cavalcanti, S.M.C. (2006) Estimating the density of a jaguar population in the Brazilian Pantanal using camera-traps and capture-recapture sampling in combination with GPS telemetry. Biological Conservation, 129, 487-496.

Trolle, M. \& Kéry, M. (2003) Estimation of ocelot density in the Pantanal using capture-recapture analysis of camera-trapping data. Journal of Mammalogy, 84, 607-614.

Wallace, R.B., Gomez, H., Ayala, G. \& Espinoza, F. (2003) Camera trapping for jaguar Panthera onca in the Tuichi Valley, Bolivia. Mastozoología Neotropical, 10, 5-11.

White, G.C., Anderson, D.R., Burnham, K.P. \& Otis, D.L. (1982) Capture-recapture and Removal Methods for Sampling Closed Populations. Los Alamos National Laboratory, Los Alamos, USA.

\section{Biographical sketches}

Agustín Paviolo has been working on research related to jaguar conservation in the Atlantic Forest since 2001. This research is focused on the factors that affect the abundance of jaguar, puma and their prey, and their conservation in the Atlantic Forest. Carlos Daniel De ANGELO conducts research on jaguar distribution and population genetics in relation to Atlantic Forest landscape fragmentation. YAMIL EDGARDo Di BLANCO is participating in various studies on the ecology and conservation of mammals in the north-east of Argentina. Mario Santiago Di Bitetti has been carrying out research in the Atlantic Forest for the last 15 years, focusing on the behaviour, ecology and conservation of primates and felids. 